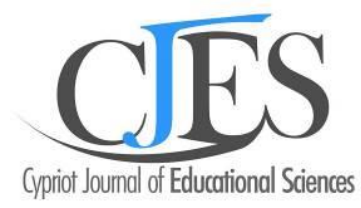

www.cjes.eu

\title{
Investigation of game perceptions of elementary school students through the pictures they draw in the context of social powers
}

Yahya Hicyilmaz *, Faculty of Education, Fine Arts Education, University of Centenary Van, Van, 65080, Turkey https://orcid.org/0000-0003-3453-9998

\section{Suggested Citation:}

Hicyilmaz, Y. (2020). Investigation of game perceptions of elementary school students through the pictures they draw in the context of social powers. Cypriot Journal of Educational Science. 15(2), 369-385. https://orcid.org/0000-0003-3453-9998

Received from February 12, 2020; revised from March 18, 2020; accepted from April 2, 2020.

${ }^{\circledR} 2020$ United World Center of Research Innovation and Publication. All rights reserved.

\begin{abstract}
This study aims to investigate the perception of games in students who study in the elementary school period through the pictures they draw in the context of social powers. In this study, the phenomenology design, one of the qualitative research designs, was used. The study group of the research consisted of a total of 1,818 students, who studied in 23 elementary schools in the Marmara, Black Sea, Central Anatolia and Eastern Anatolia regions. Within this scope, after providing the students with the required materials, the question, 'What do you think about when you hear "games"?', was asked and they were asked to draw a picture with the theme, games. The data obtained in this framework were analysed through content analysis. According to the obtained findings, it is suggested that the playgrounds enjoyed by the children should be regulated to develop their social skills.
\end{abstract}

Keywords: Elementary school, students, children's drawings, social power, game, perception.

* ADDRESS FOR CORRESPONDENCE: Yahya, Hiçyılmaz, Faculty of Education, University of Centenary Van, Van, Turkey E-mail address: yahya-04@windowslive.com 
Hicyilmaz, Y. (2020). Investigation of game perceptions of elementary school students through the pictures they draw in the context of social powers. Cypriot Journal of Educational Science. 15(2), 369-385. https://orcid.org/0000-0003-3453-9998

\section{Introduction}

When the term, game, is stated, the first image that comes to mind is generally children. Games arise as a natural activity of children. Especially in early childhood, games are used as tools for learning. At the same time, games enable children to gain a social identity (Kocyigit, Tugluk \& Kok, 2007). Within this scope, games are important tools that prepare children for adulthood, contribute to the development of various motor skills and enable them to express their feelings (Bulut \& Yilmaz, 2008; Cetinkaya, 2004; Hicyilmaz, 2015; Swindells \& Stagnitti, 2006).

Playing games is one of the basic needs of children. Children can play any game, anywhere to meet this need. Within this scope, games can be defined as activities that children enjoy. Children's drawings are generally known as a natural activity that they enjoy (Katz \& Hamama, 2013). Accordingly, it can be stated that children's drawing activity passes in the zone of games. The drawings that children use as a plain tool of expression in terms of expressing themselves to adults and peers develop along with cognitive and affective development. Verbal expressions are not needed during drawing. Children know how to draw before they master verbal expressions in their native languages (Ligorio, Schwartz, D'aprile \& Philhour, 2017). Therefore, children who have limited verbal abilities and vocabulary can easily express themselves via drawings. Within this context, children's drawings can be significant tools in getting to know children (Yavuzer, 2005).

The social behaviours and skills required in children's lives can develop via games (Durualp \& Aral, 2010; Lifter, Foster-Sand, Arzamarski, Briesch \& McClure, 2011; Saracho \& Spodek, 1995). At the same time, games enable children to gain information about themselves (Basal, 2007; Swindells \& Stagnitti, 2006; Yasar \& Paksoy, 2011). 'Because the drawings created spontaneously reflect their inner worlds, they can reflect children's development in detail when analysed exclusively' (Yavuzer, 2005, p. 11). Accordingly, it can be stated that games and children's pictures assume the role of a mirror in terms of understanding children (Hicyilmaz, 2015).

Questionnaires can collect a significant amount of data from children in semi-structured interview forms. However, because standard evaluation forms fall short in terms of determining students' perceptions, drawings can be used as a method (Rose \& Unni, 2018). Within this scope, drawings of children can provide rich data for visual research. Visual data can be analysed as a type of text (Bland, 2012). It is a fact that the individuals do not express themselves only through speaking and writing (Alerby \& Bergmark, 2012). Therefore, when children's drawings are used together with methods, such as speaking and writing, it is possible to understand their emotions, thoughts or perceptions towards anything (Chandler, 2002; Coates, 2002; Ozsoy \& Ahi, 2014). Diem-Wille (2001) stated that drawings are more powerful than words in terms of determining individuals' perceptions, beliefs or attitudes.

Pictures carry traces of tools that are effective in developing children in social terms. These tools are identified with social powers. The concept, social power, is expressed in the literature as social tools or social agents. According to Seven (2013), family, peers, school and media are significant tools in individuals' socialisation. From these tools, it can be stated that the human factor can be included in the socialisation of individuals, while the environment or a functional object can also be included. From this point of view, children's drawings can be used as a method to determine the dominant social power in children's perception of games and the types of games clarified in their minds.

Various studies on children's drawings have been conducted to date in Turkey (Ahi, Cingi \& Kıldan, 2016; Akbulut \& Saban, 2012; Ersoy \& Turkkan, 2009; Daglioglu, 2011; Guven, 2017; Hicyilmaz, Inci \& Seven, 2015; Kesicioglu \& Deniz, 2014; Ozsoy \& Ahi, 2014; Seker \& Sine, 2012; Tas, Aslan \& Sayek, 2006; Temel \& Gullu, 2016; Yalcin \& Erginer, 2014; Yasar \& Paksoy, 2011; Yilmaz \& Kahraman, 2015). These studies were rather conducted to determine the images formed in children's minds, such as teachers, violence, news, doctors, televisions, families, environments, physical education teachers, school principals, science and nature. In international studies, it was observed that the subjects investigated included matters, such as students' perceptions of classrooms (Farmer, Spearman, Qian, 
Leonard \& Rosenblith, 2018), children's perception regarding the use of digital media in preschool education (Mertala, 2016), children's perception towards determining their own learning processes (Ligorio et al., 2017), children's perceptions towards the ideal learning environment (Bland \& SharmaBrymer, 2012), determining students' perception of learning according to classroom levels (Hsieh \& Tsai, 2018) or determining students' understanding of learning science by the drawing method (Hsieh \& Tsai, 2017). Within this framework, it can be stated the number of national and international studies conducted based on children's drawings were increased. However, it was encountered that there was no study conducted to determine the dominant social powers and game images formed in the minds of students, who study at the elementary school period, through drawings. Thus, this study has importance in terms of contributing to the current limitation of the literature.

In this study, it was aimed to investigate the game perceptions of students, who study at the elementary school period, through pictures in the context of social powers. For this purpose, answers were sought for the following questions:

1. Do the dominant social powers in game-themed drawings of students differ according to their genders and classroom levels?

2. Do the types of games drawn by the students differ according to their genders and classroom levels?

3. What type of distribution do the types of games drawn by students demonstrate according to social power?

4. Do the environmental perceptions clarified in game-themed drawings of students differ according to their genders and classroom levels?

\section{Method}

\subsection{Research design}

In this study, the phenomenology design, one of the qualitative research designs, was used. Phenomenology aims to determine individuals' experiences regarding a phenomenon, namely, their conscious experiences and perceptions (Christensen, Johnson \& Turner, 2011; Yildirim \& Simsek, 2011).

\subsection{Study group}

This study was conducted with a total of 1,818 students, who studied in 23 elementary schools in the Marmara, Black Sea, Central Anatolian and Eastern Anatolian regions of Turkey during the fall season of the 2018-2019 education period. It was, especially, focused to choose schools with different socioeconomic properties. Accordingly, the maximum variation sampling method, one of purposive sampling methods, was used. By using this approach, as the basis, it was aimed to explore the main theme that covers several variations regarding the subject in question. Furthermore, it was ensured that the students participated in the study based on the principle of volunteerism. The students who did not wish to participate in the study were directed to draw anything they wanted. The demographic information of the students included in the study group of the study was presented in Table 1. 
Hicyilmaz, Y. (2020). Investigation of game perceptions of elementary school students through the pictures they draw in the context of social powers. Cypriot Journal of Educational Science. 15(2), 369-385. https://orcid.org/0000-0003-3453-9998

Table 1. Demographic information distribution of the study group

\begin{tabular}{lccc}
\hline & Demographic properties & $\boldsymbol{N}$ & $\%$ \\
\hline \multirow{2}{*}{ Gender } & Male & 906 & 49.8 \\
& Female & 912 & 50.2 \\
\hline \multirow{3}{*}{ Classroom level } & First Grade & 434 & 23.9 \\
& Second Grade & 467 & 25.7 \\
& Third Grade & 467 & 25.7 \\
\hline Total & Fourth Grade & 450 & 24.8 \\
\hline
\end{tabular}

Table 1 illustrates that $49.8 \%$ of the students were males, while $50.2 \%$ of them were females and $23.9 \%$ of them studied in first grade followed by $25.7 \%$ in second grade, $25.7 \%$ in third grade and $24.8 \%$ in fourth grade. Accordingly, it can be stated that the students constituting the study group had a balanced distribution in terms of gender and classroom levels.

\subsection{Data collection tool}

To determine the dominant social power in game perceptions and types of games clarified in the mind of students, who studied in the elementary school period, the drawing method was used as the data collection tool. It is known that the drawing is a natural way for children to express themselves to us. Within this context, Malchiodi (1998) stated that children express their feelings and thoughts to us through the drawings. This method presents a significant source to evaluate children's feelings and thoughts about the world. This is because children enjoy drawing without exhibiting a symptom of stress (Barraza, 1999). Therefore, it is believed that the drawing method was a sound way for this study.

\subsection{Data collection process}

This study was conducted within the context of the visual arts course in coordination with classroom and visual arts teachers. Before data collection, data collection and implementation instructions were created. Accordingly, the students participating in the study were handed out A4sized drawing papers. The required materials were provided for students who did not have them. The question, 'What do you think about when you hear "games"?', was written on the board. Then, the students were asked to draw a game-themed picture. The drawing was completed approximately in a lesson time. During the implementation, it was, especially, focused that there was no intervention. At the same time, it was stated that the drawings would not be evaluated for grades on any account. Then, the students were asked to fill the backside of their drawings with their demographic information and explain the drawings with answers for certain questions (Who are the people in drawings?, Where is the environment?, Which game did you draw?, etc.).

\subsection{Pilot study}

This study was aimed at students who were studying in the elementary school period and aged between 6 and 10 years. Prior to the data collection, from the students in this age group, a pilot study was conducted with students who studied in school with different socioeconomic structures. In the pilot study, visual data were collated from a total of 102 students, which included 24 first-grade students, 20 second-grade students, 28 third-grade students and 30 fourth-grade students. $48 \%$ of the students that constituted the pilot study group were females, while $52 \%$ of them were males. In conclusion, it was observed that the children in this age group correctly comprehended the specified instructions and conducted their drawings according to the instructions. The students included in the pilot study were not included in the subsequent study. 


\subsection{Data analysis}

The data obtained were analysed by the content analysis method, which is one of the qualitative analysis methods. Accordingly, it was decided to examine the visual data by two researchers. For the points of disagreements, the opinion of a third expert was referred. The researchers were chosen from expert individuals from the fields of visual arts education and classroom teaching.

The data obtained from the pilot study were entirely examined according to a certain arrangement. Then, the data (Pictures) that were not related to the subject were eliminated. The coding was conducted by constantly comparing the written texts and visual data obtained from the students. Written texts help in understanding and analysing the visual data. They also eliminate researchers' biased perceptions. Within this scope, the data triangulation method (drawing and interview method) was adopted to ensure the validity and reliability of the study. Triangulation is the practice of using the data, which are obtained from the participants with different properties, to verify each other (Yildirim \& Simsek, 2011). The data that were coded in different ways were discussed and a draft theme and a code list were created. A certain part of the visuals included images regarding a single code while other visuals included images with more than one image. The obtained codes were classified into three themes (social power, types of games and environmental perception). Then, it was continued with the analysis of the data obtained from the study group. The visual data collected from the study group underwent prescreening by examining whether the students drew them according to the instructions. In the next step, the drawings of the male students were formulised as E1 and E2, while the drawings of female students were formulised as K1 and K2. According to a certain arrangement, the data were examined thoroughly. By way of expert agreement, it was decided to include new codes to the theme, types of games. Then, in consensus, the last version of the theme and code list was formed. The codes and themes were presented in detail in the following.

The dominant social power theme in the game-themed drawings of students was formed within the framework of Seven (2013) regarding the concept of social power. Family, peers, school and media are expressed as the main social powers. Each social power was approached as a code. In line with the data obtained in the pilot study, the themes, 'family-peers' and 'peers-media', were included in this theme. Then, it was observed that the data obtained from the study group supported the draft theme and code list that was prepared. In Table 2, the codes belonging to the theme, social power and explanations of these codes along with example drawings were presented. 
Table 2. Codes belonging to social power theme and explanations and example drawings for these codes drawings

\begin{tabular}{ll}
\hline Code & \multicolumn{1}{c}{ Explanation } \\
\hline Family & $\begin{array}{l}\text { This code was assigned to drawings } \\
\text { with family and members of the } \\
\text { family. }\end{array}$
\end{tabular}

Student 'My mother, me and my sister are explanation playing games...' (K47).

Student explanation

'We are playing football with my Peers

This code was assigned to the drawings with peer groups.

$\begin{array}{ll}\text { explanation } & \text { Thiends code was assigned to drawings } \\ \text { School } & \begin{array}{l}\text { that included teachers, education } \\ \text { program and peers within school } \\ \text { borders. }\end{array}\end{array}$

Student explanation

'We are playing hide and seek in school' (E12).

\begin{tabular}{ll}
\hline Media & This code was assigned to drawings \\
& with tools such as digital games, \\
& television, tablet computers and cell \\
& phones.
\end{tabular}

Student II am choosing and playing games explanation with a gaming console' (K32). Example drawing

Example drawing




\begin{tabular}{ll}
\hline Family-Peers & $\begin{array}{l}\text { This coding was assigned to } \\
\text { drawings that included family and } \\
\text { peers together. }\end{array}$ \\
\hline $\begin{array}{l}\text { Student } \\
\text { explanation }\end{array}$ & $\begin{array}{l}\text { 'My friends came to our house. We } \\
\text { skipped ropes with my sister and } \\
\text { friends' (K667). }\end{array}$ \\
\hline Peers-Media & $\begin{array}{l}\text { This code was assigned to drawings } \\
\text { that included peers and media tools } \\
\text { together or drawings where digital } \\
\text { games were played cooperatively. }\end{array}$ \\
\hline $\begin{array}{l}\text { Student } \\
\text { explanation }\end{array}$ & $\begin{array}{l}\text { 'We are playing PlayStation with my } \\
\text { friend' (E420). }\end{array}$
\end{tabular}

The theme, types of games that are clarified in students' minds, was created by making use of the study conducted by Hicyilmaz (2015). In line with the data obtained from the pilot study, 15 codes were placed under this theme. Then, as a result of the data obtained from the study group, new codes were added and a total of 22 codes were classified under this theme.

The theme, which was designated as the environmental perception that was clarified in the mind of students in their game-themed drawings, was determined as seven codes according to the data obtained from the pilot study. Then, it was observed that the data obtained from the study group verified the draft code list prepared. No new code was added. As it stands, the draft code was finalised by the researcher. The coding regarding this theme was conducted as shown in Table 3.

Table 3. Codes belonging to the environmental perceptions that were clarified in the game-themed pictures of students

\begin{tabular}{cl}
\hline Code & Explanation \\
\hline House & This code was assigned to the drawings that were in a house and within the border a yard. \\
School & This code was assigned to the drawings that were related to schools (playgrounds, \\
classrooms, buildings, teachers, students, etc.) \\
Park & This code was assigned to all drawings regarding park areas. \\
Street & This code was assigned to all drawings regarding streets. \\
Natural environment & This code was assigned to green areas, where no structure, such as beaches, pools or \\
buildings, existed. & \\
Football field & This code was only assigned to the drawings that had a football field shape. \\
Basketball field & This code was only assigned to the drawings that had a basketball field shape. \\
Digital environment & This code was assigned to the drawings of environments that were inspired by the media. \\
\hline
\end{tabular}


Hicyilmaz, Y. (2020). Investigation of game perceptions of elementary school students through the pictures they draw in the context of social powers. Cypriot Journal of Educational Science. 15(2), 369-385. https://orcid.org/0000-0003-3453-9998

\section{Findings}

3.1. Findings about the first sub-question of research that 'Do the dominant social powers in game-themed drawings of students differ according to their genders and classroom levels?'

Table 4. Distribution of the dominant social power in game-themed drawings of students according to their genders and classroom levels

\begin{tabular}{|c|c|c|c|c|c|c|c|c|}
\hline \multirow[b]{2}{*}{ Variables } & \multirow{2}{*}{$f / \%$} & \multicolumn{6}{|c|}{ Social power } & \multirow[b]{2}{*}{ Total } \\
\hline & & Family & Peers & School & Media & Family-Peers & Peers-Media & \\
\hline \multirow[t]{2}{*}{ Female } & $f$ & 183 & 408 & 214 & 44 & 50 & 7 & 906 \\
\hline & $\%$ & 20.2 & 45.0 & 23.6 & 4.9 & 5.5 & .8 & 100 \\
\hline \multirow[t]{2}{*}{ Male } & $f$ & 105 & 346 & 174 & 214 & 42 & 31 & 912 \\
\hline & $\%$ & 11.5 & 37.9 & 19.1 & 23.5 & 4.6 & 3.4 & 100 \\
\hline \multirow[t]{2}{*}{ Total } & $f$ & 288 & 754 & 388 & 258 & 92 & 38 & 1818 \\
\hline & $\%$ & 15.8 & 41.5 & 21.3 & 14.2 & 5.1 & 2.1 & 100 \\
\hline \multirow[t]{2}{*}{ First grade } & $f$ & 106 & 147 & 90 & 65 & 18 & 8 & 434 \\
\hline & $\%$ & 24.4 & 33.9 & 20.7 & 15 & 4.1 & 1.8 & 100 \\
\hline \multirow[t]{2}{*}{ Second grade } & $f$ & 84 & 201 & 107 & 55 & 12 & 8 & 467 \\
\hline & $\%$ & 18 & 43 & 22.9 & 11.8 & 2.6 & 1.7 & 100 \\
\hline \multirow[t]{2}{*}{ Third grade } & $f$ & 41 & 202 & 102 & 78 & 35 & 9 & 467 \\
\hline & $\%$ & 8.8 & 43.3 & 21.8 & 16.7 & 7.5 & 1.9 & 100 \\
\hline \multirow[t]{2}{*}{ Fourth grade } & $f$ & 57 & 204 & 89 & 60 & 27 & 13 & 450 \\
\hline & $\%$ & 12.7 & 45.3 & 19.8 & 13.3 & 6 & 2.9 & 100 \\
\hline \multirow[t]{2}{*}{ Total } & $f$ & 288 & 754 & 388 & 258 & 92 & 38 & 1818 \\
\hline & $\%$ & 15.8 & 41.5 & 21.3 & 14.2 & 5.1 & 2.1 & 100 \\
\hline
\end{tabular}

Table 4 illustrates that the dominant social power in the students' game-themed drawings was peers $(41.5 \%)$. In terms of dominant social power, it was observed that the theme, peers, was followed by school (21.3\%), family (15.8\%), media (14.2\%), family-peers $(5.1 \%)$ and peers-media (2.1\%), respectively.

Table 4 illustrates in terms of gender distributions, it was observed that the perceptual difference was rather observed in drawings where family and media were the dominant social powers. It was determined that females (20.2\%) drew more pictures where the family was the dominant social power compared to males (11.5\%). It was also observed that males $(23.5 \%)$ drew more pictures where media was the dominant social power compared to females (4.9\%).

Table 4 illustrates in terms of classroom level, it was observed that the perceptual difference was observed in drawings where the family was the dominant social power. It was determined that students in first-grade (24.4\%) drew more pictures where the family was the dominant social power compared to students in second (18\%), third $(8.8 \%)$ and fourth $(12.7 \%)$ grades. In addition, it was observed that the students in first-grade (33.9\%) drew fewer pictures where peers were the dominant social power compared to students in second (43\%), third (43.3\%) and fourth (45.3\%) grades.

3.2. Findings about the second sub-question of the research that 'Do the types of games drawn by students differ according to their genders and classroom levels?' 
Table 5. Distribution of the types of games drawn by students according to their genders and classroom levels

\begin{tabular}{|c|c|c|c|c|c|c|c|c|}
\hline \multirow{2}{*}{ Game } & \multirow{2}{*}{$f / \%$} & \multicolumn{2}{|c|}{ Gender } & \multicolumn{4}{|c|}{ Classroom level } & \multirow[b]{2}{*}{ Total } \\
\hline & & Female & Male & First grade & Second grade & Third grade & Fourth grade & \\
\hline \multirow{2}{*}{ Football } & $f$ & 105 & 343 & 87 & 105 & 142 & 114 & 448 \\
\hline & $\%$ & 11.6 & 37.6 & 20 & 22.5 & 30.4 & 25.3 & 24.6 \\
\hline \multirow{2}{*}{ Skipping rope } & $f$ & 227 & 56 & 27 & 69 & 88 & 99 & 283 \\
\hline & $\%$ & 25.1 & 6.1 & 6.2 & 14.8 & 18.8 & 22 & 15.6 \\
\hline \multirow{2}{*}{ Hide and seek } & $f$ & 109 & 98 & 53 & 55 & 58 & 41 & 207 \\
\hline & $\%$ & 12 & 10.7 & 12.2 & 11.8 & 12.4 & 9.1 & 11.4 \\
\hline \multirow{2}{*}{ Basketball } & $f$ & 20 & 64 & 6 & 28 & 23 & 27 & 84 \\
\hline & $\%$ & 2.2 & 7 & 1.4 & 6 & 4.9 & 6 & 4.6 \\
\hline \multirow{2}{*}{ Cartoon heroes } & $f$ & 12 & 22 & 20 & 6 & 7 & 1 & 34 \\
\hline & $\%$ & 1.3 & 2.4 & 4.6 & 1.3 & 1.5 & 0.2 & 1.9 \\
\hline \multirow{2}{*}{ Hopscotch } & $f$ & 106 & 33 & 35 & 23 & 35 & 46 & 139 \\
\hline & $\%$ & 11.7 & 3.6 & 8.1 & 4.9 & 7.5 & 10.2 & 7.6 \\
\hline \multirow{2}{*}{ Volleyball } & $f$ & 55 & 34 & 10 & 29 & 14 & 36 & 89 \\
\hline & $\%$ & 6.1 & 3.7 & 2.3 & 6.2 & 3 & 8 & 4.9 \\
\hline \multirow{2}{*}{ Swimming } & $f$ & 7 & 16 & 8 & 2 & 2 & 11 & 23 \\
\hline & $\%$ & 0.8 & 1.8 & 1.8 & 0.4 & 0.4 & 2.4 & 1.3 \\
\hline \multirow{2}{*}{$\begin{array}{l}\text { Playing with park } \\
\text { equipment }\end{array}$} & $f$ & 125 & 120 & 48 & 41 & 78 & 78 & 245 \\
\hline & $\%$ & 13.8 & 13.2 & 11.1 & 8.8 & 16.7 & 17.3 & 13.5 \\
\hline \multirow{2}{*}{ Toys } & $f$ & 51 & 13 & 23 & 20 & 8 & 13 & 64 \\
\hline & $\%$ & 5.6 & 1.4 & 5.3 & 4.3 & 1.7 & 2.9 & 3.5 \\
\hline \multirow{2}{*}{ Digital games } & $f$ & 31 & 118 & 51 & 38 & 34 & 26 & 149 \\
\hline & $\%$ & 3.4 & 12.9 & 11.8 & 8.1 & 7.3 & 5.8 & 8.2 \\
\hline \multirow{2}{*}{ Jackstones } & $f$ & 4 & 3 & 2 & 1 & 1 & 3 & 7 \\
\hline & $\%$ & 0.4 & 0.3 & 0.5 & 0.2 & 0.2 & 0.7 & 0.4 \\
\hline \multirow{2}{*}{ Blind man's bluff } & $f$ & 39 & 14 & 5 & 26 & 14 & 8 & 53 \\
\hline & $\%$ & 4.3 & 1.5 & 1.2 & 5.6 & 3 & 1.8 & 2.9 \\
\hline \multirow{2}{*}{ Dodgeball } & $f$ & 27 & 8 & 4 & 14 & 9 & 8 & 35 \\
\hline & $\%$ & 3 & 0.9 & 0.9 & 3 & 1.9 & 1.8 & 1.9 \\
\hline \multirow{2}{*}{ Tag } & $f$ & 21 & 16 & 20 & 9 & 5 & 3 & 37 \\
\hline & $\%$ & 2.3 & 1.8 & 4.6 & 1.9 & 1.1 & 0.7 & 2 \\
\hline \multirow{2}{*}{ Snowball } & $f$ & 11 & 7 & 10 & 6 & 1 & 1 & 18 \\
\hline & $\%$ & 1.2 & 0.8 & 2.3 & 1.3 & 0.2 & 0.2 & 1 \\
\hline \multirow{2}{*}{ Dance } & $f$ & 15 & 7 & 8 & 8 & 2 & 4 & 22 \\
\hline & $\%$ & 1.7 & 0.8 & 1.8 & 1.7 & 0.4 & 0.9 & 1.2 \\
\hline & $f$ & 7 & 5 & 2 & 3 & 5 & 2 & 12 \\
\hline IVlusıcal chaırs & $\%$ & 0.8 & 0.5 & 0.5 & 0.6 & 1.1 & 0.4 & 0.7 \\
\hline & $f$ & 16 & 11 & 11 & 7 & 3 & 6 & 27 \\
\hline Kite & $\%$ & 1.8 & 1.2 & 2.5 & 1.5 & 0.6 & 1.3 & 1.5 \\
\hline Handkerchief & $f$ & 15 & 6 & 16 & 1 & 0 & 4 & 21 \\
\hline capture & $\%$ & 1.7 & 0.7 & 3.7 & 0.2 & 0 & 0.9 & 1.2 \\
\hline & $f$ & 3 & 8 & 0 & 6 & 1 & 4 & 11 \\
\hline Table tennis & $\%$ & 0.3 & 0.9 & 0 & 1.3 & 0.2 & 0.9 & 0.6 \\
\hline & $f$ & 10 & 6 & 4 & 4 & 4 & 4 & 16 \\
\hline Chess & $\%$ & 1,1 & 0,7 & 0,9 & 0,9 & 0,9 & 0,9 & 0,9 \\
\hline
\end{tabular}

Table 5 illustrates that 22 different types of games were observed in the drawings of the students. It was also observed that most of the students drew types of games such as football (24.6\%), skipping 
rope $(15.6 \%)$, playing with park equipment $(13.5 \%)$, hide and seek $(11.4 \%)$, digital games $(8.2 \%)$, hopscotch (7.6\%), volleyball (4.9\%) and basketball (4.6\%).

Table 5 shows that in terms of gender distribution, it was revealed that the perceptual difference was present at drawings where types of games, such as football, skipping rope, hopscotch, digital games, basketball and toys, were included. Males (37.6\%) drew more pictures that covered football games compared to females (11.6\%). It was observed that the skipping rope type of game was drawn by $25.1 \%$ of the females, while $6.1 \%$ of the males drew that type. Hopscotch type of game was drawn by $11.7 \%$ of the females and $3.6 \%$ of the males. It was determined that males $(12.9 \%)$ drew more pictures that covered digital games types compared to females (3.4\%). Males (7\%) drew the basketball type of game compared to females (2.2\%). It was also observed that playing with toys type game was drawn by $5.6 \%$ of the females and $1.4 \%$ of the males.

Table 5 shows that in terms of classroom levels, it was revealed that the perceptual difference was rather observed in pictures where football, skipping rope, playing with park equipment, digital games, volleyball, basketball, blind man's bluff, cartoon heroes and handkerchief capture types of games were drawn. It was determined that students in third-grade drew more pictures with football type of game compared to students in other classroom levels (first grade $20 \%$, second grade $22.5 \%$ and fourth grade $25.3 \%$ ). As the classroom levels of students increased (first grade $6.2 \%$, second grade $14.8 \%$, third grade $18.8 \%$ and fourth grade $22 \%$ ), it was observed that they drew skipping rope type of game more. It was determined that playing with park equipment type of game drawings of students differed depending on their classroom levels (first grade $11.1 \%$, second grade $8.8 \%$, third grade $16.7 \%$ and fourth grade $17.3 \%$ ). It was also determined that the digital game type was drawn fewer as the classroom levels increased (first grade $11.8 \%$, second grade $8.1 \%$, third grade $7.3 \%$ and fourth grade $5.8 \%)$. In volleyball type game drawings of the students, it was determined there were differences according to classroom levels (first grade $2.3 \%$, second grade $6.2 \%$, third grade $3.4 \%$ and fourth grade $8 \%)$. For basketball type game, the students in first grade $(1.4 \%)$ drew fewer pictures compared to students at other classroom levels (second grade $6 \%$, third grade $4.9 \%$ and fourth grade $6 \%$ ). In playing with toys drawings of students, it was determined there were differences according to their classroom levels (first grade $5.3 \%$, second grade $4.3 \%$, third grade $1.7 \%$ and fourth grade $2.9 \%$ ). Similarly, it was determined that blind man's bluff type of game drawings of students differed according to the classroom levels (first grade 1.2\%, second grade 5.6\%, third grade $3 \%$ and fourth grade $1.8 \%$ ). Furthermore, it was determined that students in first grade $(3.7 \%)$ drew more pictures with handkerchief capture game compared to students at other classroom levels (second grade $0.2 \%$, third grade $0 \%$ and fourth grade $0.9 \%$ ).

3.3. Findings about the third sub-question of research that 'What type of distribution do the types of games drawn by students demonstrate according to social power?' 
Table 6. Distribution of type of games drawn by students according to social power

\begin{tabular}{|c|c|c|c|c|c|c|c|c|}
\hline Type of games & $f / \%$ & Family & Peers & School & Media & Family-Peers & Peers-Media & Tota \\
\hline \multirow{2}{*}{ Football } & $f$ & 49 & 182 & 101 & 89 & 21 & 6 & 448 \\
\hline & $\%$ & 2.7 & 10 & 5.6 & 4.9 & 1.2 & 0.3 & 24.6 \\
\hline \multirow{2}{*}{ Skipping rope } & $f$ & 37 & 151 & 79 & 0 & 16 & 0 & 283 \\
\hline & $\%$ & 2 & 8.3 & 4.3 & 0 & 0.9 & 0 & 15.6 \\
\hline \multirow{2}{*}{ Hide and seek } & $f$ & 31 & 123 & 47 & 0 & 6 & 0 & 207 \\
\hline & $\%$ & 1.7 & 6.8 & 2.6 & 0 & 0.3 & 0 & 11.4 \\
\hline \multirow{2}{*}{ Basketball } & $f$ & 8 & 29 & 31 & 11 & 3 & 2 & 84 \\
\hline & $\%$ & 0.4 & 1.6 & 1.7 & 0.6 & 0.2 & 0.1 & 4.6 \\
\hline \multirow{2}{*}{ Cartoon heroes } & $f$ & 0 & 0 & 0 & 34 & 0 & 0 & 34 \\
\hline & $\%$ & 0 & 0 & 0 & 1.9 & 0 & 0 & 1.9 \\
\hline \multirow{2}{*}{ Hopscotch } & $f$ & 16 & 61 & 55 & 0 & 7 & 0 & 139 \\
\hline & $\%$ & 0.9 & 3.4 & 3 & 0 & 0.4 & 0 & 7.6 \\
\hline \multirow{2}{*}{ Volleyball } & $f$ & 12 & 39 & 27 & 3 & 7 & 1 & 89 \\
\hline & $\%$ & 0.7 & 2.1 & 1.5 & 0.2 & 0.4 & 0.1 & 4.9 \\
\hline \multirow{2}{*}{ Swimming } & $f$ & 9 & 11 & 0 & 0 & 3 & 0 & 23 \\
\hline & $\%$ & 0.5 & 0.6 & 0 & 0 & 0.2 & 0 & 1.3 \\
\hline \multirow{2}{*}{$\begin{array}{l}\text { Playing with park } \\
\text { equipment }\end{array}$} & $f$ & 48 & 152 & 17 & 0 & 28 & 0 & 245 \\
\hline & $\%$ & 2.6 & 8.4 & 0.9 & 0 & 1.5 & 0 & 13.5 \\
\hline \multirow{2}{*}{ Toys } & $f$ & 46 & 10 & 2 & 0 & 6 & 0 & 64 \\
\hline & $\%$ & 2.5 & 0.6 & 0.1 & 0 & 0.3 & 0 & 3.5 \\
\hline \multirow{2}{*}{ Digital games } & $f$ & 0 & 0 & 0 & 118 & 0 & 31 & 149 \\
\hline & $\%$ & 0 & 0 & 0 & 6.5 & 0 & 1.7 & 8.2 \\
\hline \multirow{2}{*}{ Jackstones } & $f$ & 0 & 3 & 3 & 0 & 1 & 0 & 7 \\
\hline & $\%$ & 0 & 0.2 & 0.2 & 0 & 0.1 & 0 & 0.4 \\
\hline \multirow{2}{*}{ Blind man's bluff } & $f$ & 7 & 24 & 18 & 0 & 4 & 0 & 53 \\
\hline & $\%$ & 0.4 & 1.3 & 1 & 0 & 0.2 & 0 & 2.9 \\
\hline \multirow{2}{*}{ Dodge ball } & $f$ & 8 & 16 & 11 & 0 & 0 & 0 & 35 \\
\hline & $\%$ & 0.4 & 0.9 & 0.6 & 0 & 0 & 0 & 1.9 \\
\hline \multirow{2}{*}{ Tag } & $f$ & 6 & 18 & 11 & 0 & 2 & 0 & 37 \\
\hline & $\%$ & 0.3 & 1 & 0.6 & 0 & 0.1 & 0 & 2 \\
\hline \multirow{2}{*}{ Snowball } & $f$ & 5 & 12 & 0 & 0 & 0 & 1 & 18 \\
\hline & $\%$ & 0.3 & 0.7 & 0 & 0 & 0 & 0.1 & 1 \\
\hline \multirow{2}{*}{ Dance } & $f$ & 5 & 9 & 6 & 1 & 1 & 0 & 22 \\
\hline & $\%$ & 0.3 & 0.5 & 0.3 & 0.1 & 0.1 & 0 & 1.2 \\
\hline \multirow{2}{*}{ Musical chairs } & $f$ & 1 & 5 & 6 & 0 & 0 & 0 & 12 \\
\hline & $\%$ & 0.1 & 0.3 & 0.3 & 0 & 0 & 0 & 0.7 \\
\hline \multirow{2}{*}{ Kite } & $f$ & 9 & 10 & 7 & 0 & 1 & 0 & 27 \\
\hline & $\%$ & 0.5 & 0.6 & 0.4 & 0 & 0.1 & 0 & 1.5 \\
\hline \multirow{2}{*}{$\begin{array}{c}\text { Handkerchief } \\
\text { capture }\end{array}$} & $f$ & 4 & 1 & 16 & 0 & 0 & 0 & 21 \\
\hline & $\%$ & 0.2 & 0.1 & 0.9 & 0 & 0 & 0 & 1.2 \\
\hline \multirow{2}{*}{ Table tennis } & $f$ & 1 & 4 & 4 & 1 & 1 & 0 & 11 \\
\hline & $\%$ & 0.1 & 0.2 & 0.2 & 0.1 & 0.1 & 0 & 0.6 \\
\hline \multirow{2}{*}{ Chess } & $f$ & 5 & 2 & 7 & 1 & 1 & 0 & 16 \\
\hline & $\%$ & 0.3 & 0.1 & 0.4 & 0.1 & 0.1 & 0 & 0.9 \\
\hline
\end{tabular}

As it can be seen in Table 6, it was determined that the dominant social power was peers in types of games, such as football (10\%), skipping rope $(8.3 \%)$, hide and seek $(6.8 \%)$, hopscotch $(3.4 \%)$, volleyball (2.1\%), playing with park equipment $(8.4 \%)$, blind man's bluff $(1.3 \%)$, dodge ball $(0.9 \%)$, tag (1\%), snowball $(0.7 \%)$ and dance $(0.5 \%)$. Additionally, it was determined that in types of games, such as basketball $(1.7 \%)$, musical chairs $(0.3 \%)$, handkerchief capture $(0.9 \%)$ and chess $(0.4 \%)$, the dominant 
social power was school while family was the dominant social power in toys $(2.5 \%)$ type of game followed by the media as the dominant social power in the type of games, such as digital games (6.5\%) and cartoon heroes (1.9\%).

3.4. Findings about the fourth sub-question of research that 'Do the environmental perceptions clarified in game-themed drawings of students differ according to their genders and classroom levels?'

Table 7. Distribution of students' environmental perceptions that was clarified in game-themed pictures according to their genders and classroom levels

\begin{tabular}{|c|c|c|c|c|c|c|c|c|}
\hline \multirow{2}{*}{ Environment } & \multirow{2}{*}{$f / \%$} & \multicolumn{2}{|c|}{ Gender } & \multicolumn{4}{|c|}{$\begin{array}{c}\text { Classroom Level } \\
\end{array}$} & \multirow[b]{2}{*}{ Total } \\
\hline & & Female & Male & First grade & Second grade & Third grade & Fourth grade & \\
\hline House & $f$ & 180 & 104 & 97 & 77 & 51 & 59 & 284 \\
\hline \multirow{3}{*}{ School } & $\%$ & 9.9 & 5.7 & 5.3 & 4.2 & 2.8 & 3.2 & 15.6 \\
\hline & $f$ & 214 & 175 & 92 & 106 & 99 & 92 & 389 \\
\hline & $\%$ & 11.8 & 9.6 & 5.1 & 5.8 & 5.4 & 5.1 & 21.4 \\
\hline \multirow[t]{2}{*}{ Park } & $f$ & 148 & 116 & 47 & 47 & 84 & 86 & 264 \\
\hline & $\%$ & 8.1 & 6.4 & 2.6 & 2.6 & 4.6 & 4.7 & 14.5 \\
\hline \multirow[t]{2}{*}{ Street } & $f$ & 76 & 74 & 57 & 50 & 22 & 21 & 150 \\
\hline & $\%$ & 4.2 & 4.1 & 3.1 & 2.8 & 1.2 & 1.2 & 8.3 \\
\hline \multirow{2}{*}{$\begin{array}{c}\text { Natural } \\
\text { environment }\end{array}$} & $f$ & 241 & 146 & 68 & 106 & 102 & 111 & 387 \\
\hline & $\%$ & 13.3 & 8 & 3.7 & 5.8 & 5.6 & 6.1 & 21.3 \\
\hline \multirow[t]{2}{*}{ Football field } & $f$ & 4 & 75 & 9 & 20 & 23 & 27 & 79 \\
\hline & $\%$ & 0.2 & 4.1 & 0.5 & 1.1 & 1.3 & 1.5 & 4.3 \\
\hline \multirow[t]{2}{*}{ Basketball field } & $f$ & 2 & 13 & 4 & 4 & 4 & 3 & 15 \\
\hline & $\%$ & 0.1 & 0.7 & 0.2 & 0.2 & 0.2 & 0.2 & 0.8 \\
\hline \multirow{2}{*}{$\begin{array}{c}\text { Digital } \\
\text { environment }\end{array}$} & $f$ & 41 & 209 & 60 & 57 & 82 & 51 & 250 \\
\hline & $\%$ & 2.3 & 11.5 & 3.3 & 3.1 & 4.5 & 2.8 & 13.8 \\
\hline \multirow{2}{*}{ Total } & $f$ & 906 & 912 & 434 & 467 & 467 & 450 & 1818 \\
\hline & $\%$ & 49.8 & 50.2 & 23.9 & 25.7 & 25.7 & 24.8 & 100 \\
\hline
\end{tabular}

According to the data in Table 7, it was observed that students' game-themed pictures included more schools $(21.4 \%)$ and natural environments $(21.3 \%)$ as environments. It was determined that most of the females drew environments, such as natural environments (13.3\%), schools (11.8\%), houses $(9.9 \%)$ and parks $(8.1 \%)$ in their pictures. It was also determined that males drew environments, such as digital environments (11.5\%) and football fields (4.1\%). Moreover, it was observed that first-grade students drew more houses (5.3\%) and streets (3.1\%) in their environment drawings, while second-grade students drew more schools (5.8\%) and natural environments (5.8\%). It was also observed that students in third grade drew more digital environments (5.8\%), while students in fourth grade drew more parks (4.7\%) and football fields (1.5\%).

\section{Discussion, conclusion and suggestions}

Socialisation occurs within a certain process. In this process, the development level and psychological characteristics of individuals are also affected. In addition, social powers, such as family, school, peers and media play roles in individuals' socialisation (Seven, 2013). Determining the social powers effective in students' socialisation is believed to be effective in raising mentally healthy people. Within this scope, when the findings regarding the first sub-problem of the study were examined, it was determined that the dominant social power in the students' game-themed pictures 
was peers (41.5\%). Peer relationships play important roles in children's learning and gaining positive interpersonal communications (Seven, 2013). Therefore, it can be stated that peers, which is one of the social figures, play vital roles in students' games. According to the findings of the first subproblem, one of the most important results was the fact that the media and family social powers had significant differences in terms of gender and classroom levels. In game-themed pictures drawn by the students, it was concluded that females drew pictures where family social power was more effective compared to males, while males drew pictures where media social power was more effective compared to females. Furthermore, first-grade students drew more pictures where family social power was covered compared to students at other classroom levels. In the most critical periods of human life, family is expressed under the influence of social power. Family can affect children's future socialisation positively or negatively. Within this framework, according to the results obtained, it can be stated that as the ages and classroom levels of students increased, the social power of family was decreased, and based on this, different social powers could become effective. Moreover, it can be expressed that in game-themed pictures, the differentiation of social power depending on students' gender roles is a natural process.

When the findings of the second sub-problem of the study were examined, it was concluded that the students drew 22 different types of games. Children in the elementary school period view everything as an opportunity for games (Glenn, Knight, Holt \& Spence, 2013). Thus, children perceive an entertaining situation as a game (Kocyigit \& Baydilek, 2015; Miller \& Kuhaneck, 2008; Pilten \& Pilten, 2013). Accordingly, it can be stated that children in the elementary school period perceived certain activities like games and drew them. One of the most important results of the second subproblem is that the students drew the football (24.6\%) type of game more compared to other games. Eristi (2010) explains this situation with the widespread characteristic of football in popular culture. In studies conducted by Hicyilmaz (2015), and Temel and Gullu (2016), this finding was supported. Within this scope, it can be stated that football type of games became popular for students, due to students' communication with each other and the effects of the media. Thus, this situation affects students' game-themed drawings.

When students' drawings were investigated in terms of gender, it was observed that males drew football (37.6\%) and digital game (11.7\%) type of games, while females drew pictures that covered game types, such as skipping rope (25.3\%) and hopscotch $(11.7 \%)$. The difference in terms of gender also shows itself in many fields of life (Blakemore, Berenbaum \& Liben, 2009). It is known that males and females traditionally differ in terms of choosing toys (Cuceloglu, 2002; Weisgram, Fulcher \& Dinella, 2014). Within this context, it can be stated that it is a natural conclusion that there is a difference between the types of games drawn by students differ depending on gender. In a study conducted by Pilten and Pilten (2013), it was observed that the types of games played by children differed depending on the gender. In a study conducted by Kaya, Karakas, Pacaci and Erzeybek (2017), it was reported that females liked playing house games more while males liked playing computer games more. Accordingly, these findings coincide with the findings of our study.

One of the most important conclusions of the second sub-problem of the study is that as the classroom levels of the students increased, types of games, such as football, playing with park equipment and skipping rope were drawn more. Additionally, it was concluded that as the classroom levels increased, cartoon heroes and digital game types, where the effects of digital media culture are present, were drawn fewer. However, in a study conducted by Sapsaglam (2018), it was observed that as the age group increased, children were more interested in digital games. Prensky (2011) stated that the age factor was an important one for children in their preference for digital games. These results contradict the findings of our study. With reference to the findings of the second sub-problem, it can be stated that age, mental development, experience or education level of students can affect the types of games they draw.

When the findings of the third sub-problem of the study were examined, it was determined that the dominant social power was peers in types of games, such as football, skipping rope, hide and seek, 
hopscotch, volleyball, playing with park equipment, blind man's bluff, dodge ball, tag, snowball and dance. Furthermore, it was concluded that the dominant social power was school in types of games, such as basketball, musical chairs, handkerchief capture and chess while family was the dominant social power in toys type of games followed by the media as the dominant social power in type of games, such as cartoon heroes and digital games. Especially, in the football game type drawn by the students, it was determined that the media also had a powerful effect in addition to the other social powers. Accordingly, it can be stated that different social powers were effective in the pictures drawn by students according to the types of games. Considering the fact that socialisation is a process, determining the social powers effective in this process is important in order to raise compatible people (Seven, 2013).

Children can view almost everywhere as a playground, including streets and natural environments (Holt, Lee, Millar \& Spence, 2015). Accordingly, when the findings of the fourth sub-problem of the study were examined, it was observed that the children drew different environments, such as houses, schools, parks, streets, natural environments, football fields, basketball fields and digital environments. Furthermore, it was concluded that the students drew schools and natural environments more. In a study conducted by Kaya et al. (2017), it was observed that the most commonly preferred playgrounds for children included parks and yards. In a study conducted by Candan, Kaya and Erzeybek (2013), it was observed that yards and streets stood out as playgrounds. It can be stated that these findings support the results of our study in a way. It was determined that most of the females included natural environments (13.3\%) in their pictures while males included digital environments (11.5\%) in their pictures. Moreover, it was concluded that first-grade students included more houses (5.3\%) in their pictures while second-grade students included schools (5.8\%) and natural environments (5.8\%). It was also observed that third-grade students drew more digital environments (5.8\%) while students in fourth grade covered more parks (4.7\%). Within this context, it can be stated that depending on the socialisation process of students, their preferences of environment drawings differ according to their classroom levels.

Considering the conclusions of the study, it can be stated that socialisation is a process and difference social powers can be effective in this process depending on genders and classroom levels. Students need to experience a positive socialisation process in order to adapt to social norms. Accordingly, we can state that important duties fall onto the shoulders of families and teachers. In order to reduce the negative effects of media in children for whom media has effective social powers, the control of media tools should be ensured. Furthermore, it is believed that families should guide children in choosing their peers. Within this framework, potential damages to the social skills of children in game environments that they enjoy can be prevented. For children to socialise in a positive way, experts and architects of child development should build safe and comfortable playgrounds within cooperation.

\section{References}

Ahi, B., Cingi, M. A. \& Kildan, A. O. (2016). 48-60 Aylik cocukların ogretmen kavramına yonelik algılarının cizimler araciligiyla incelenmesi [Examining 48-60 months old children's perceptions about teacher concept by analyzing their drawings]. Elementary Education Online, 15(1), 77-90. http://dx.doi.org/10.17051/io.2016.97994

Akbulut, M. G. \& Saban, A. (2012). Ilkogretim ogrencilerinin siddetle ilgili algilarinin cizdikleri resimler araciligiyla incelenmesi [An investigation of primary school students' perceptions of violence revealed through their drawings]. Turkish Journal of Education, 1(1), 21-37. https://doi.org/10.19128/turie.181040

Alerby, E. \& Bergmark, U. (2012). What can an image tell? Challenges and benefits of using visual art as a research method to voice lived experiences of students and teachers. Journal of Arts and Humanities, 1(1), 95-104. https://doi.org/10.18533/journal.v1i1.9

Barraza, L. (1999). Children's drawings about the environment. Environmental Education Research, 5(1), 49-66. https://doi.org/10.1080/1350462990050103

Basal, H. A. (2007). Gecmis yillarda Turkiye'de cocuklar tarafindan oynanan cocuk oyunlari [Kids games played by children in Turkey in the past year]. Uludag Universitesi Egitim Fakultesi Dergisi, 20(2), 243-266. Retrieved from 
Hicyilmaz, Y. (2020). Investigation of game perceptions of elementary school students through the pictures they draw in the context of social powers. Cypriot Journal of Educational Science. 15(2), 369-385. https://orcid.org/0000-0003-3453-9998

https://dergipark.org.tr/en/pub/uefad/issue/16686/173392

Blakemore, J., Berenbaum, S. A. \& Liben, L. S. (2009). Gender development. New York, NY: Psychology Press.

Bland, D. (2012). Analysing children's drawings: applied imagination. International Journal of Research \& Method in Education, 35(3), 235-242. https://doi.org/10.1080/1743727X.2012.717432

Bland, D. \& Sharma-Brymer, V. (2012). Imagination in school children's choice of their learning environment: an Australian study. International Journal of Educational Research, 56, 75-88. https://doi.org/10.1016/i.ijer.2012.06.002

Bulut, Z. \& Yilmaz, S. (2008). Permaculture playgrounds as a new design approach for sustainable society. International Journal of Natural \& Engineering Sciences, 2(2), 35-40. Retrieved from http://citeseerx.ist.psu.edu/viewdoc/download?doi=10.1.1.464.9385\&rep=rep1\&type=pdf

Candan, N., Kaya, F. \& Erzeybek, M.S. (2013, Aralik). Farkli okul turundeki ogrencilerin cocuk oyunlarına iliskin goruslerinin incelenmesi [Examination of the views of different school type students on children's games]. ICHPER •SD Dünya Kongresinden sunulmus bildiri, Istanbul, Turkiye.

Chandler, D. (2002). Textual interactions'. In semiotics: the basics. London, UK: Routledge.

Christensen, L. B., Johnson, R. B. \& Turner, L. A. (2011). Research methods, design, and analysis (11th ed.). Boston, MA: Pearson.

Coates, E. (2002). 'I forgot the sky' children's stories contained within their drawings. International Journal of Early Years, 10(1), 21-35. https://doi.org/10.1080/09669760220114827

Cuceloglu, D. (2002). Insan ve davranisi [Man and his behavior]. Istanbul, Turkey: Remzi Kitabevi.

Cetinkaya, B. (2004). Ruhsal acidan saglikli aile saglikli çocuk [Spiritually healthy family healthy child]. Ankara, Turkey: Pegem Yayincilik.

Daglioglu, H. E. \& Deniz, U. (2011). Okul oncesi donem cocuklarının insan figuru cizimlerinin gelisimsel acidan cinsiyete gore incelenmesi [A study on human figure drawings of preschool students and their differences showed by gender]. Elektronik Sosyal Bilimler Dergisi, 10(35), 16-30. Retrieved from https://dergipark.org.tr/en/pub/esosder/issue/6149/82563

Diem-Wille, G. (2001). A therapeutic perspective: the use of drawings in child psychoanalysis and social science. In T. V. Leeuwen \& C. Jewitt (Eds.), Handbook of visual analysis (pp. 119-133). London, UK: Sage.

Durualp, E. \& Aral, N. (2010). Alti yasindaki cocukların sosyal becerilerine oyun temelli sosyal beceri egitiminin etkisinin incelenmesi [A study on the effects of play-based social skills training on social skills of six-year-old children]. Hacettepe Universitesi Egitim Fakultesi Dergisi, 39(39), 160-172. Retrieved from https://dergipark.org.tr/en/pub/hunefd/issue/7799/102172

Eristi, S. D. (2010). Ilkogretim ogrencilerinin resimsel anlatimlarında populer kultur algisi (norvec cok kulturlu fjell ilkogretim okulu ornegi) [Primary school students' popular culture perception in their pictures (the example of multicultural Fjell primary school in Norway]. Ilkogretim Online, 9(3), 884-897. Retrieved from https://hdl.handle.net/11421/11198

Ersoy, A. \& Turkkan, B. (2009). Perceptions about Internet in elementary school children's drawings. Elementary Education Online, 8(1), 57-73. Retrieved from http://ilkogretim-online.org.tr/index.php/io/article/viewFile/1686/1522

Farmer, J. L., Spearman, M., Qian, M., Leonard, A. E. \& Rosenblith, S. (2018). Using children's drawings to examine student perspectives of classroom climate in a school-within-a-school elementary school. The Elementary School Journal, 118(3), 384-408. Retrieved from https://www.journals.uchicago.edu/doi/pdfplus/10.1086/696194

Glenn, N. M., Knight, C. J., Holt, N. L. \& Spence, J. C. (2013). Meanings of play among children. Childhood, 20(2), 185-199. https://doi.org/10.1177/0907568212454751

Guven, S. (2017). Determination of the perceptions of primary school students regarding the concept of television. Journal of Education and Training Studies, 5(8), 151-166. https://doi.org/10.11114/jets.v5i8.2554

Hsieh, W. M. \& Tsai, C. C. (2017). Exploring students' conceptions of science learning via drawing: a cross-sectional analysis. International Journal of Science Education, 39(3), 274-298. https://doi.org/10.1080/09500693.2017.1280640

Hsieh, W. M. \& Tsai, C. C. (2018). Learning illustrated: an exploratory cross-sectional drawing analysis of students' conceptions of learning. The Journal of Educational Research, 111(2), 139-150. https://doi.org/10.1080/00220671.2016.1220357

Hicyilmaz Y. (2015, 7-8 Mayis). Ilkokul Ogrencilerinin gunluk yasantilarinda oyun algilarinin resim yoluyla incelenmesi [Study of game perception of primary students through pictures in daily life]. Uluslararası Oyun ve Oyuncak Kongresinden sunulmuş bildiri, Erzurum, Türkiye.

Hicyilmaz, Y., Inci, M. A. \& Seven, S. (2015). 7-10 yas grubu cocuklarin siddet algilarinin resimler araciligiyla sosyal gucler baglaminda incelenmesi [Examining the perception of violence of the children between 7-10 ages through the paintings in the context of social forces]. International Periodical for the Languages, Literature and History of Turkish or Turkic, 10(15), 503-518. https://doi.org/7827/TurkishStudies.8535

Holt, N. L., Lee, H., Millar, C. A. \& Spence, J. C. (2015). 'Eyes on where children play': a retrospective study of active free play. Children's Geographies, 13(1), 73-88. https://doi.org/10.1080/14733285.2013.828449

Katz, C. \& Hamama, L. (2013). "Draw me everything that happened to you": exploring children's drawings of sexual abuse. Children and Youth Services Review, 35(5), 877-882. https://doi.org/10.1016/j.childyouth.2013.02.007 
Hicyilmaz, Y. (2020). Investigation of game perceptions of elementary school students through the pictures they draw in the context of social powers. Cypriot Journal of Educational Science. 15(2), 369-385. https://orcid.org/0000-0003-3453-9998

Kaya, F., Karakas, L., Pacaci, S. \& Erzeybek, M. S. (2017). Devlet ve ozel okullarda ogrenim goren cocukların cocuk oyunlarına iliskin goruslerinin incelenmesi [The analysis of the opinions of the children in private and public schools regarding children's games]. Ataturk Universitesi Kazim Karabekir Egitim Fakultesi Dergisi, 34, 19-29. Retrieved from https://dergipark.org.tr/en/pub/ataunikkefd/issue/29687/301437

Kesicioglu, O. S. \& Deniz, U. (2014). Investigation of pre-school children's perception of teacher in their drawings. Creative Education, 5(08), 606-613. https://doi.org/10.4236/ce.2014.58071

Kocyigit, S., Tugluk, M. N. \& Kok, M. (2007). Cocugun gelisim surecinde egitsel bir etkinlik olarak oyun [Play as educational activity in the child's development process]. Ataturk Universitesi Kazim Karabekir Egitim Fakultesi Dergisi, (16), 324-342. Retrieved from https://dergipark.org.tr/en/download/article-file/31587

Lifter, K., Foster-Sanda, S., Arzamarski, C., Briesch, J. \& McClure, E. (2011). Overview of play: Its uses and importance in early intervention/early childhood special education. Infants \& Young Children, 24(3), 225-245. https://doi.org/10.1097/IYC.0b013e31821e995c

Ligorio, M. B., Schwartz, N. H., D'Aprile, G. \& Philhour, D. (2017). Children's representations of learning through drawings. Learning, Culture and Social Interaction, 12(1), 133-148. doi:10.1016/j.Icsi.2016.12.004

Malchiodi C. A. (1998) Understanding children's drawings. New York, NY: The Guilford Press.

Mertala, P. (2016). Fun and games-Finnish children's ideas for the use of digital media in preschool. Nordic Journal of Digital Literacy, 11(04), 207-226. Retrieved from https://www.idunn.no/dk/2016/04/fun and games finnish childrens ideas for the use of dg

Miller, E. \& Kuhaneck, H. (2008). Children's perceptions of play experiences and play preferences: a qualitative study. American Journal of Occupational Therapy, 62(4), 407-415. doi:10.5014/ajot.62.4.407

Ozsoy, S. \& Ahi, B. (2014). Ilkokul ogrencilerinin gelecege yonelik cevre algilarinin cizdikleri resimler araciligi ile belirlenmesi. Kuram ve Uygulamada Egitim Bilimleri, 14(4), 1557-1582. Retrieved from https://docplayer.biz.tr/26068238-Ilkokulogrencilerinin-gelecege-yonelik-cevre-algilarinin-cizdikleri-resimler-araciligi-ile-belirlenmesi.html

Pilten, P. \& Pilten, G. (2013). Okul cagı cocuklarinin oyuna iliskin algilarinin degerlendirilmesi. Mersin Universitesi Egitim Fakultesi Dergisi, 9(2), 15-31. Retrieved from https://dergipark.org.tr/en/pub/mersinefd/issue/17383/181536

Prensky, M. (2001). Digital game-based learning. New York, NY: McGraw-Hill.

Rose, T. M., \& Unni, E. J. (2018). Using drawings to probe the affective experience of pharmacy students on rotation: a pilot study. Currents in Pharmacy Teaching and Learning, 10, 1033-1040. https://doi.org/10.1016/j.cptl.2018.05.011

Sapsaglam, O. (2018). Okul oncesi donem cocuklarının degisen oyun tercihleri [Changing game preferences of preschool children]. Journal of Kirsehir Education Faculty, 19(1), 1122-1135. Retrieved from http://kefad.ahievran.edu.tr/InstitutionArchiveFiles/f44778c7-ad4a-e711-80ef-00224d68272d/d1a3a581-af4a-e71180ef-00224d68272d/Cilt19Sayi1/313699d5-51d0-45a6-a0c8-f4e49a168e6f 20180427001.pdf

Saracho, O. N. \& Spodek, B. (1995). Children's play and early childhood education: insights from history and theory. Journal of Education, 177(3), 129-148. https://doi.org/10.1177/002205749517700308

Seven, S. (2013). Cocuk ruh sagligi [Child mental health]. Ankara, Turkey: Pegem Akademi Yayinlari.

Swindells, D. \& Stagnitti, K. (2006). Pretend play and parents' view of social competence: the construct validity of the ChildInitiated Pretend Play Assessment. Australian Occupational Therapy Journal, 53(4), 314-324. doi:10.1111/j.14401630.2006.00592.x

Seker, T. \& Sine, R. (2012). Cocuk zihnindeki haber resmi [The news picture in child's mind]. Global Media Journal, Spring, 4(2), 118-137. Retrieved

from https://globalmediajournaltr.yeditepe.edu.tr/sites/default/files/Tu\%CC\%88lay\%20S\%CC\%A7EKER\%20\%20Rengim\%20SI\%CC\%87NE.pdf

Tas, Y., Aslan, D. \& Sayek, I. (2006). Doktorluk meslegini cocuklar resimlerine nasıl yansitiyorlar? 7-12 yas grubu cocuklar arasinda yapilmis bir ornek [How do children reflect the "physician" profession to their drawings? an example conducted among children between 7 and 12 years of age]. Surekli Tıp Egitimi Dergisi, 15(11), 184-191. Retrieved from https https://www.researchgate.net/profile/Yasemin Tas Torun2/publication/297380851

Temel, C. \& Gullu, M. (2016). Bir beden egitimi dersi ciz [Draw a physical education lesson]. Egitim ve Bilim Dergisi, 41(183), 351-361. https://doi.org/10.15390/EB.2016.5106

Yasar, M. \& Paksoy I. (2011). Cizgi filmlerdeki saldırgan icerikli goruntulerin, cocukların serbest oyunlari sirasındaki saldirganlik duzeylerine etkisi [The effects of cartoons with aggressif images on childrens' aggresiveness level during their free play]. Cukurova Universitesi Sosyal Bilimler Enstitusu Dergisi, 20(2), 279-298. Retrieved from https://dergipark.org.tr/en/pub/cusosbil/issue/4387/60290

Weisgram, E. S., Fulcher, M. \& Dinella, L. M. (2014). Pink gives girls permission: exploring the roles of explicit gender labels and gender-typed colors on preschool children's toy preferences. Journal of Applied Developmental Psychology, 35(5), 401-409. https://doi.org/10.1016/j.appdev.2014.06.004

Yalcin, M. \& Erginer, A. (2014). Ilkogretim okulu ogrencilerinin okul muduru algılarına iliskin yaptiklari cizimler [Primary school students's drawings on the perceptions of school principal]. Egitim ve Bilim, 39(171), 270-285. Retrieved from https 
Hicyilmaz, Y. (2020). Investigation of game perceptions of elementary school students through the pictures they draw in the context of social powers. Cypriot Journal of Educational Science. 15(2), 369-385. https://orcid.org/0000-0003-3453-9998

http://eb.ted.org.tr/index.php/EB/article/view/2301

Yavuzer, H. (2005). Resimleriyle cocuk [Child with pictures]. Istanbul, Turkey: Remzi Kitap Evi.

Yıldırım, A. \& Simsek, H., (2011). Sosyal bilimlerde nitel araştırma yontemleri [Qualitative research methods in the social sciences] (8th ed.). Ankara, Turkey: Seckin.

Yilmaz, F. \& Kahraman, A. D. (2015). Science and nature perception in the Images and pictures of the children. Procedia-Social and Behavioral Sciences, 176, 650-658. https://doi.org/10.1016/i.sbspro.2015.01.523 